\title{
Efektivitas Layanan Penguasaan Konten Menggunakan Model Pembelajaran Kooperatif Tipe Think Pair Share untuk Meningkatkan Keterampilan Bertanya Siswa dalam Belajar
}

\author{
Aldio Kyoto Putra 1, Firman 2, Syahniar 3 \\ ${ }^{123}$ Universitas Negeri Padang \\ *Corresponding author, e-mail: kyotoaldio@gmail.com
}

\begin{abstract}
Student with low asking skills tend to experience obstader in the learning process. Actually, the effort given by the counseling teacher hasn't reached the taarget sa expected. This study aims to see the effectiveness of content mastery services using cooperative learning model type think pair share, to improve student questioning skills. This study uses a quantitative approch with design quasy experiment type the non equivalent control group in SHS N 1 Sungai Limau Kab. Padang Pariaman. The subjects are XI IPS 1 \& 3 class. Data collection techniques used questionnaire, than analyzed by different test technique wilcoxon and t-test. Research result show content mastery services used cooperative learning model type think pair share can improved student questioning skill and more effectiv than content mastery service without used learning model. Counseling teachers are expected to improve student's questioning skill throught countent mastery services used cooperative learning proccess type think pair share.
\end{abstract}

Keyword: content mastery services, cooperative learning model type think pair share, student questioning skills.

How to Cite: Aldio Kyoto Putra 1, Firman 2, Syahniar 3. 2018. Efektivitas Layanan Penguasaan Konten Menggunakan Model Pembelajaran Kooperatif Tipe Think Pair Share Untuk Meningkatkan Keterampilan Bertanya Siswa dalam Belajar. Konselor, VV (N): pp. XXXX,DOI:10.24036/XXXXXXXXXX-X-XX

\section{Pendahuluan}

Pendidikan memiliki peranan penting bagi manusia dalam menghadapi perkembangan dan pembangunan bangsa dan negara. Pendidikan diperlukan oleh manusia untuk meningkatkan kualitas hidup, mewujudkan diri sesuai dengan tahapan tugas perkembangan secara optimal sehingga mencapai taraf kedewasaan tertentu, serta memiliki kemampuan dalam keilmuan dan ketaqwaan. Pendidikan juga merupakan suatu usaha atau kegiatan yang dijalankan dengan sengaja, teratur dan berencana dengan maksud mengubah atau mengembangkan perilaku yang diinginkan.

Berhasil atau gagalnya pencapaian tujuan pendidikan itu amat bergantung pada proses belajar yang dialami siswa baik ketika ia berada di sekolah maupun di lingkungan rumah atau keluarganya sendiri. Belajar bukan hanya keharusan, melainkan kebutuhan.Hal ini sesuai dengan yang dikatakan oleh Piaget (dalam Muhibbin Syah, 2012:104) semenjak kelahirannya, setiap anak manusia memiliki kebutuhan yang melekat dalam dirinya sendiri untuk belajar.

Natawidjaja (1999) menjelaskan terdapat dua faktor yang dapat mempengaruhi prestasi belajar siswa yaitu faktor internal dan faktor eksternal. Faktor internal dalam belajar adalah faktor yang ada dalam diri seperti intelegensi atau kecerdasan, kepribadian, bakat, minat, sikap serta keterampilan belajar, sedangkan faktor eksternal adalah faktor yang dapat mempengaruhi yang timbul dari luar diri individu yaitu keluarga, lingkungan dan masyarakat. Keterampilan belajar merupakan faktor yang dimungkinkan dapat mempengaruhi hasil belajar siswa.Ada berbagai macam hal yang bisa dijadikan pedoman untuk melihat keterampilan belajar. Prayitno \& dkk (1997:18) merumuskan sejumlah pedoman yang dapat dijadikan panduan dalam setiap kali mengikuti kegiatan belajar sebagaimana yang terdapat dalam seri latihan 
keterampilan belajar yaitu: (1) memilih tempat duduk dalam ruang kelas, (2) mencatat materi , (3) bertanya dan menjawab, (4) mengemukakan pendapat dan (5) berupaya menghindarkan diri dari berbagai pengaruh yang mengganggu konsentrasi belajar.

Keterampilan belajar adalah sesuatu yang dirasakan sangat perlu dimiliki dan selalu ditingkatkan oleh siswa.Gie (2002:76) menjelaskan keterampilan belajar dianggap mampu untuk bisa menjadi patokan individu yang berbeda-beda dalam meningkatkan hasil belajar. Keterampilan belajar adalah seperangkat sistem, metode dan teknik yang baik dalam menguasai materi pengetahuan yang disampaikan guru secara tangkas, efektif dan efisien.

Berdasarkan hasil observasi yang dilakukan pada 10 dan 11 juli tahun 2017 di kelas XI IPS 1 dan 3 SMA Negeri 1 Sungi Limau, diketahui bahwa suasana belajar cenderung terlihat kurang aktif saat sedang berlangsungnya pembelajaran. Saat guru selesai menjelaskan suatu materi, guru mempersilahkan siswa untuk bertanya, namun siswa terlihat tidak antusias untuk bertanya. Mereka mengatakan jika mereka kurang memiliki keberanian dalam bertanya. Lalu ada juga beberapa siswa yang mengaku jika dia sering merasa bosan ketika hendak mencoba mengulang pelajaran di rumah. Terlihat pula bahwa siswa cenderung tidak aktif saat berlangsungnya pembelajaran sehingga kelas menjadi kaku. Saat pembelajaran berlangsungpun siswa terlihat melakukan kegiatan yang tidak berhubungan dengan pembelajaran.

Berdasarkan wawancara dengan guru BK yang dilaksanakan pada tanggal 11 Juli 2017 di ruang BK SMA Negeri 1 Sungai Limau, diketahui ada siswa yang memiliki motivasi yang rendah untuk menggali dan memperdalam pengetahuan yang mereka miliki, dikarenakan selama proses pembelajaran berlangsung, siswa enggan untuk bertanya baik dengan kemauannya sendiri ataupun ketika diberi kesempatan oleh guru. Kemudian saat ditanyai oleh guru kenapa siswa enggan bertanya, mereka menjawab jika mereka ragu untuk bertanya karena merasa memiliki kemampuan yang lemah dalam hal bertanya. Hal tersebut disebabkan karena siswa tidak terampil dalam menandai poin materi yang hendak dijadikan pertanyaan, siswa tidak mempersiapkan pertanyaan sebelum pembelajaran dimulai, siswa yang tidak paham menyampaikan agar pertanyaan yang dia ajukan bisa tidak berbelit-belit dan jelas.

Untuk mengatasi hal tersebut, diberikan bantuan kepada siswa dengan melaksanakan pelayanan bimbingan dan konseling. Willi P., Firman, \& Afrizal S. (2013), menjelaskan bimbingan adalah proses pemberian bantuan yang dilakukan oleh seorang ahli kepada individu dengan menggunakan berbagai prosedur, cara dan bahan agar individu tersebut mampu mandiri dalam memecahkan masalah-masalah yang dihadapinya, sedangkan konseling merupakan proses pemberian bantuan yang didasarkan pada prosedur wawancara konseling oleh seorang ahli kepada yang bermuara pada teratasinya masalah yang dihadapi klien. Khairul Amri, Syahniar \& Herman Nirwana (2014) menjelaskan Pelayanan bimbingan dan konseling merupakan salah satu komponen penting pendidikan di sekolah. Pentingnya bimbingan dan konseling tidak terlepas dari tujuan bimbingan konseling itu sendiri. Tujuan bimbingan konseling adalah untuk membantu perkembangan diri siswa seoptimal mungkin. Jika kegiatan belajar mengajar berorientasi pada peningkatan kecerdasan intelektual, maka kegiatan bimbingan dan konseling di sekolah secara spesifik berorientasi membantu seluruh aspek-aspek perkembangan diri siswa

Pelayanan bimbingan dan konseling yang dilakukan salah satunya adalah layanan penguasaan konten. Di sekolah guru BK mempunyai tugas dan tanggung jawab membantu siswa dalam meningkatkan hasil belajar yang optimal dengan mendorong siswa dengan kebiasaan-kebiasaan yang baik dalam kegiatan belajar (Hezy, Firman \& Ifdil, 2014). Pemberian Layanan Penguasaan Konten (PKO) merupakan layanan bantuan kepada individu (sendiri ataupun kelompok) untuk menguasai kemampuan atau kompetensi tertentu melalui kegiatan belajar (Prayitno, 2012:89). Berbagai keterampilan itu meliputi keterampilan dasar membaca, menulis, menghitung, keterampilan mengikuti pelajaran di dalam kelas, membuat catatan, bertanya, dan menjawab (baik lisan, maupun tulisan), mengerjakan tugas, membuat laporan, menyusun makalah, menyiapkan dan mengikuti ujian, serta menindaklanjuti hasil mengerjakan tugas, ulangan, atau ujian (Prayitno, 1988).

Dewa Ketut Sukardi \& Desak (2008) menjelaskan layanan penguasaan konten dimaksudkan untuk memungkinkan siswa memahami dan mengembangkan sikap dan kebiasaan belajar yang baik, keterampilan dan materi belajar yang cocok dengan kecepatan dan kesulitan belajarnya, serta tuntutan kemampuan yang berguna dalam kehidupan dan perkembangan dirinya. Dalam upaya peningkatkan keterampilan belajar dalam proses pembelajaran tentulah menggunakan model pembelajaran yang inovatif dan progresif. Hal ini dimaksudkan agar proses belajar lebih efektif. Soekamto dkk (dalam Trianto, 2009: 22) menjelaskan model pembelajaran adalah kerangka konseptual yang melukiskan prosedur yang sistematis dalam mengorganisasikan pengalaman belajar untuk mencapai tujuan belajar tertentu, dan 
berfungsi sebagai pedoman bagi para perancang pembelajaran dan para pengajar dalam merencanakan aktivitas belajar mengajar.

Di tengah semakin baiknya perhatian pemerintah dalam mengokohkan keberadaan bimbingan dan konseling di instansi pendidikan, pelaksanaan kegiatan bimbingan dan konseling di sekolah menjadi tantangan tersediri bagi Guru BK sebagai pelaksana utama dalam kegiatan tersebut. Profesionalitas Guru BK sangat dituntut dalam melaksanakan pelayanan BK yang optimal bagi peserta didik seiring dengan semakin diakuinya keberadaan bimbingan dan konseling di instansi pendidikan (Satya, Syahniar \& Daharnis, 2014). Selama ini, layanan penguasaan konten yang dilaksanakan oleh guru BK tidak dipadukan dengan model pembelajaran inovatif dan kreatif.

Khairul, Syahniar \& Herman (2014) menjelaskan bahwa untuk menguasai dan meningkatkan kemampuan mengemukakan pendapat, diperlukan berbagai strategi dan pendekatan khusus bagi siswa. Dirasakan perlunya suatu model pembelajaran khusus dalam pelaksanaan layanan penguasaan konten agar upaya pembelajaran menjadi lebih menarik dan hasilnya lebih baik lagi, salah satu model pembelajaran yang bisa digunakan adalah pembelajaran model pembelajaran kooperatif. Penggunaan model pembelajaran kooperatif bukan sekedar membiasakan diri belajar berkelompok saja, tetapi dapat melatihkan siswa bekerja secara mandiri. Model yang demikian menjadikan siswa terbiasa mencari bahan pelajaran serta memecahkan masalah dengan mandiri, belajar bekerja sama dan menjalin komunikasi yang baik antar sesama teman. Model belajar yang baik akan meningkatkan aktivitas belajar dan hasil belajar.

Salah satu model pembelajaran kooperatif adalah Think-Pair-Share (TPS). Model think-pair-share berkembang dari penelitian belajar kooperatif dan waktu tunggu. Frang Lyman (dalam Trianto, 2009: 132) menjelaskan think-pair-share merupakan suatu cara yang efektif untuk membuat variasi suasana pola diskusi kelas dengan asumsi bahwa prosedur yang digunakan dalam think-pair-share dapat memberi siswa lebih banyak waktu berpikir, untuk merespons dan saling membantu.

Syiddik Khutami (2015) menjelaskan terdapat peningkatan keterampilan belajar siswa melalui layanan penguasaan konten di SMAN 1 Bonjol Kabupaten Pasaman. Ranifah Yuniarti (2013) dalam hasil penelitiannya yang dilakukan di SDN Karanganyar 02 Semarang menjelaskan model think pair share dengan video pembelajaran dapat meningkatkan keterampilan guru, aktifitas siswa dan keterampilan berbicara siswa dalam pembelajaran bahasa Indonesia. Amri Nur Syihab (2013) menjelaskan secara umum keterampilan komunikasi dan hasil belajar dengan menerapkan model think-pair-share pada mata pelajaran kompetensi kejuruan lebih baik dibandingkan dengan keterampilan komunikasi siswa tanpa menggunakan model pembelajaran. Berdasarkan hasil analisis pada penelitian Penerapan Model Pembelajaran think-pairshare melalui public speaking untuk meningkatkan keterampilan komunikasi siswa pada mapel kompetensi kejuruan kompetensi dasar MC kelas X1 AP 1 jurusan administrasi perkantoran SMK N 2 Blora tahun ajaran 2012/2013 didapatkan peningkatan keterampilan komunikasi siswa pada mata pelajaran kompetensi kejuruan dengan penerapan model pembelajaran TPS.

Aninditya Sri Nugraheni (2012), menjelaskan terjadi peningkatan kualitas pembelajaran (baik proses maupun hasil) pada keterampilan berbicara siswa kelas V Madrasah Ibtidaiyah Pucangan, Kartasura, Sukoharjo. Peningkatan kualitas pembelajaran dengan penerapan strategi think-pair-share, yaitu ini terbukti siswa menjadi lebih berani setelah dilatih oleh guru dengan menggunakan strategi think-pair-share, siswa yang lebih berperan aktif dalam mengikuti pelajaran, siswa menjadi merasa tertantang untuk bisa ikut aktif dalam proses pembelajaran.

Bertitik tolak dari hal di atas, maka sudah selayaknya sebagai guru bimbingan dan konseling di sekolah menindaklanjuti permasalahan tersebut dengan cara meningkatkan keterampilan bertanya siswa dalam hal menandai materi pelajaran, menulis pertanyaan, meminta kesempatan bertanya, dan mengajukan pertanyaan dengan singkat dan jelas.

\section{Metode}

Jenis penelitian ini yaitu penelitian eksperimen rancangan Quasi-Experiment jenis the non equivalent control group. Subjek penelitiannya yaitu siswa kelas X IPS 1 sebagai kelompok eksperimen dan siswa kelas XI IPS 3 sebagai kelompok kontrol di SMA N 1 Sei.Limau Kabupaten Padang Pariaman yang memiliki tingkat keterampilan bertanya dalam belajar yang rendah.Instrumen yang digunakan dalam pengumpulan data yaitu kuesioner (angket). Data tentang keterampilan bertanya siswa dalam belajar dikumpulkan melalui angket keterampilan bertanya yang diberikan pada saat pretest dan posttest, kemudian dianalisis dengan bantuan program Statistical Product and Service Solution (SPSS) versi 16.00. Untuk menguji perbedaan tingkat keterampilan bertanya siswa sebelum dan sesudah diberikan perlakuan 
digunakan uji Wilcoxon Signed Rank Test. Sedangkan untuk melihat perbedaan keterampilan bertanya siswa antara kelompok eksperimen dan kelompok kontrol menggunakan uji t-test.

\section{Hasil dan Pembahasan}

Bab ini menguraikan hasil penelitian yang didasarkan pada tujuan penelitian, yaitu: (1)Perbedaan keterampilan bertanya siswa kelompok eksperimen sebelum dan setelah diberikan perlakuan layanan penguasaan konten yang menggunakan model pembelajaran kooperatif tipe think pair share, (2)Perbedaan keterampilan bertanya siswa kelompok kontrol sebelum dan setelah diberikan layanan penguasaan konten tanpa model pembelajaran kooperatif tipe think pair share, (3)Perbedaan keterampilan bertanya siswa kelompok eksperimen yang diberi perlakuan layanan penguasaan konten menggunakan model pembelajaran kooperatif tipe think pair share dengan kelompok kontrol yang diberi perlakuan tanpa model pembelajaran kooperatif tipe think pair share, maka hasil penelitian ini dapat diuraikan sebagai berikut :

\section{Pengujian Hipotesis Pertama}

Hipotesis pertama, yaitu Terdapat perbedaan yang signifikan pada keterampilan bertanya siswa pada kelompok eksperimen sebelum diberikan layanan penguasaan konten dan sesudah diberikan perlakuan layanan penguasaan konten dengan model pembelajaran kooperatif tipe think pair share (TPS), yang hasil perhitungannya dapat dilihat pada tabel berikut ini.

Tabel 2

Distribusi Frekuensi Pretest dan Posttest keterampilan bertanya siswa dalam Belajar Kelompok Eksperimen

\begin{tabular}{|c|c|c|c|c|c|}
\hline \multirow{2}{*}{ Interval } & \multirow{2}{*}{ Kategori } & \multicolumn{2}{|c|}{ Pretest } & \multicolumn{2}{c|}{ Posttest } \\
\cline { 3 - 6 } & & $\mathrm{F}$ & $\%$ & $\mathrm{~F}$ & $\%$ \\
\hline$\geq 152$ & Sangat tinggi & 2 & 7 & 3 & 10 \\
\hline $123-151$ & Tinggi & 9 & 31 & 17 & 59 \\
\hline $94-122$ & Sedang & 10 & 34 & 9 & 31 \\
\hline $65-93$ & Rendah & 8 & 28 & 0 & 0 \\
\hline$\leq 64$ & $\begin{array}{c}\text { Sangat } \\
\text { rendah }\end{array}$ & 0 & 0 & 0 & 0 \\
& Jumlah & 29 & 100 & 29 & 100 \\
\hline
\end{tabular}

Untuk lebih jelasnya dapat dilihat pada diagram berikut:

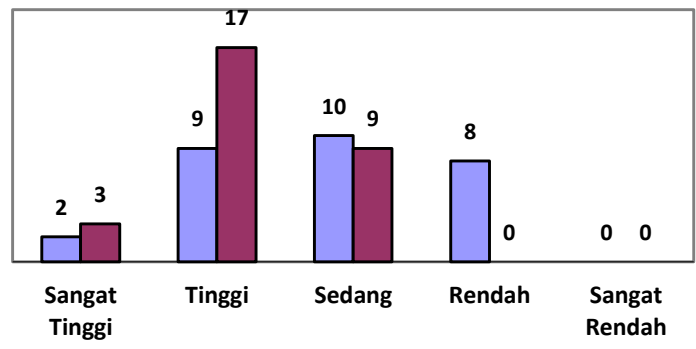

口Pretest 口Posttest

Gambar 1

Diagram Hasil Pretest dan Posttest Keterampilan Bertanya Siswa dalam Belajar Kelompok Eksperimen 
Sementara itu, berdasarkan hasil uji beda (t-test) diperoleh hasil sebagai berikut.

Tabel 3

Hasil Analisis Wilcoxon Signed Rangked Test Perbedaan Keterampilan Bertanya Siswa dalam Belajar pada Pretest dan Posttest Kelompok Eksperimen

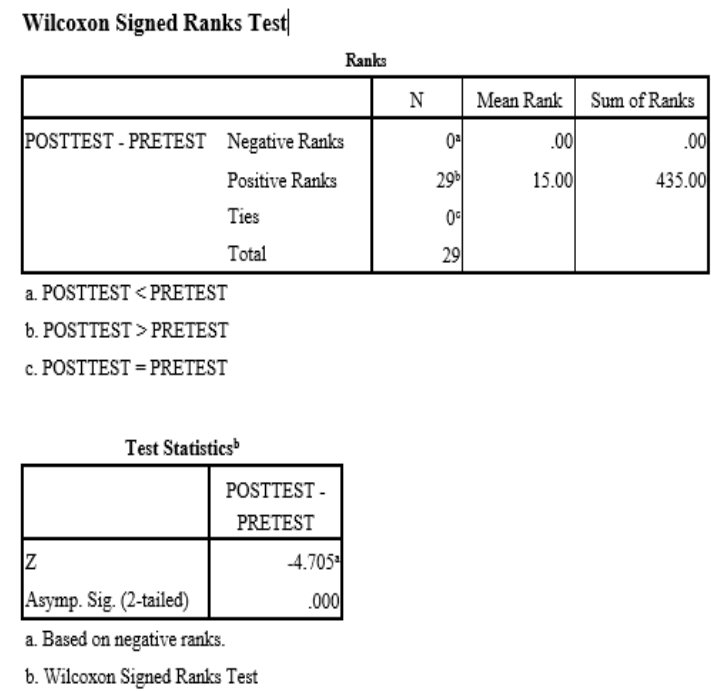

Dari hasil perhitungan tersebut diperoleh nilai Asymp. Sig. (2-tailed) lebih kecil dari taraf signifikansi $0,05(0,000<0,05)$. Dengan demikian, hipotesis pertama pada penelitian ini dapat diterima, dimana terdapat perbedaan yang signifikan pada keterampilan bertanya siswa dalam belajar kelompok eksperimen sebelum dan sesudah diberi layanan penguasaan konten menggunakan model pembelajaran kooperatif tipe think pair share.

\section{Pengujian Hipotesis Kedua}

Hipotesis kedua, yaitu Tidak terdapat yang signifikan pada keterampilan bertanya siswa pada kelompok kontrol sebelum dan sesudah diberikan perlakuan layanan penguasaan konten tanpa model pembelajaran, yang hasil perhitungannya dapat dilihat pada tabel berikut ini.

Tabel 4

Distribusi Frekuensi Pretest dan Posttest Keterampilan Bertanya Siswa dalam Belajar Kelompok Kontrol

\begin{tabular}{|c|c|c|c|c|c|}
\hline \multirow{2}{*}{ Interval } & \multirow{2}{*}{ Kategori } & \multicolumn{2}{|c|}{ Pretest } & \multicolumn{2}{c|}{ Posttest } \\
\cline { 3 - 6 } & & $\mathrm{F}$ & $\%$ & $\mathrm{~F}$ & $\%$ \\
\hline$\geq 152$ & Sangat tinggi & 0 & 0 & 0 & 0 \\
\hline $123-151$ & Tinggi & 11 & 38 & 13 & 45 \\
\hline $94-122$ & Sedang & 13 & 45 & 16 & 55 \\
\hline $65-93$ & Rendah & 5 & 17 & 0 & 0 \\
\hline$\leq 64$ & Sangat rendah & 0 & 0 & 0 & 0 \\
\hline \multicolumn{2}{|c|}{ Jumlah } & 29 & 100 & 29 & 100 \\
\hline
\end{tabular}


Untuk lebih jelasnya dapat dilihat pada diagram berikut:

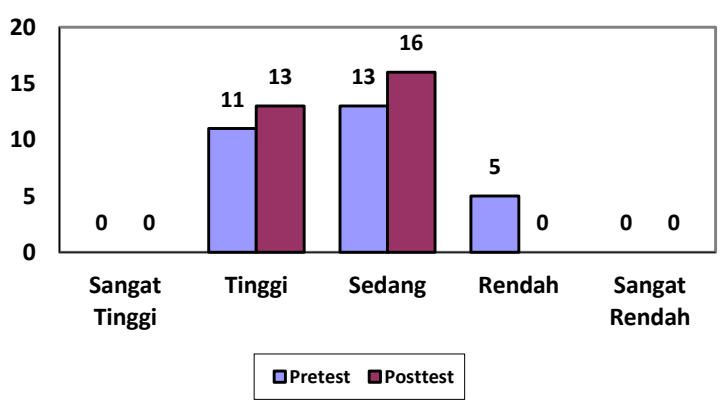

Gambar 2

Diagram Hasil Pretest Dan Posttest Keterampilan Bertanya Siswa dalam Belajar Kelompok Eksperimen

Sementara itu, berdasarkan hasil uji beda (t-test) diperoleh hasil sebagai berikut.

Tabel 5

Hasil Analisis Uji $t$-test Keterampilan Bertanya Siswa dalam Belajar pada Pretest dan Posttest Kelompok Kontrol

Wilcoxon Signed Ranks Test

\begin{tabular}{|ll|r|r|r|}
\hline & \multicolumn{1}{|c|}{ Ranks } \\
\hline POSTTEST - PRETEST & Negative Ranks & $3^{\circ}$ & 10.83 & Mean Rank \\
& Positive Ranks & $23^{\circ}$ & 13.85 & 32.50 \\
& Ties & $3^{\circ}$ & & \\
& Total & 29 & & \\
\hline
\end{tabular}

a. POSTTEST $<$ PRETEST

b. POSTTEST $>$ PRETEST

c. POSTTEST $=$ PRETEST

|

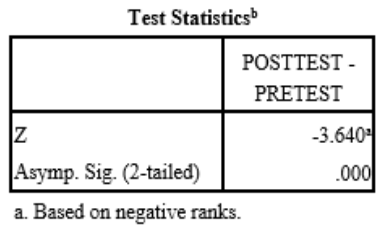

b. Wilcoxon Signed Ranks Test

Dari hasil perhitungan tersebut diperoleh nilai Asymp. Sig. (2-tailed) lebih besar dari taraf signifikansi 0,05 $(0,000>0,05)$. Dengan demikian, hipotesis kedua pada penelitian ini dapat diterima, dimana tidak terdapat perbedaan yang signifikan pada pada keterampilan bertanya siswa dalam belajar kelompok kontrol tanpa model pembelajaran.

\section{Pengujian Hipotesis Ketiga}

Hipotesis ketiga, yaitu Terdapat perbedaan yang signifikan pada keterampilan bertanya siswa antara kelompok eksperimen yang mengikuti layanan penguasaan konten dengan model pembelajaran kooperatif tipe Think Pair Share (TPS) dan keterampilan bertanya siswa kelompok kontrol yang mengikuti layanan penguasaan konten tanpa model pembelajaran, yang hasil perhitungannya dapat dilihat pada tabel berikut ini. 


\section{Tabel 6 \\ Hasil Analisis Uji t-test Keterampilan Bertanya Siswa dalam Belajar Kelompok Eksperimen dengan Kelompok Kontrol Setelah Diberikan Perlakuan}

\begin{tabular}{|c|c|c|c|c|c|c|}
\hline $\begin{array}{c}\text { Keterampilan } \\
\text { bertanya siswa } \\
\text { dalam Belajar }\end{array}$ & $\begin{array}{c}\text { Post } \\
\text { test }\end{array}$ & Mean & $\begin{array}{c}\text { Std. } \\
\text { Deviation }\end{array}$ & $\mathrm{T}$ & $\mathrm{df}$ & $\begin{array}{c}\text { Sig. } \\
\text { (2-tailed) }\end{array}$ \\
\cline { 2 - 7 } & Eksperimen & 130.83 & 15.342 & 2.872 & 56 & .006 \\
\cline { 2 - 7 } & Kontrol & 120.00 & 13.299 & & & \\
\hline
\end{tabular}

Dari hasil perhitungan tersebut diperoleh nilai Asymp. Sig. (2-tailed) lebih kecil dari taraf signifikansi $0,05(0,006<0,05)$. Dengan demikian, hipotesis ketiga pada penelitian ini dapat diterima, dimana terdapat perbedaan yang signifikan pada keterampilan bertanya siswa dalam belajar antara kelompok eksperimen yang mengikuti layanan penguasaan konten menggunakan model pembelajaran kooperatif tipe think pair share dan keterampilan bertanya siswa dalam belajar kelompok kontrol yang mengikuti layanan penguasaan konten tanpa model pembelajaran.

Temuan pada penelitian ini adalah terdapat perbedaan yang signifikan pada keterampilan bertanya siswa kelompok eksperimen dan kelompok kontrol. Untuk lebih memahami hasil penelitian secara konseptual, berikut akan dijelaskan pembahasan terhadap temuan penelitian.

1. Perbedaan Keterampilan bertanya Siswa dalam Belajar Kelompok Eksperimen (Pretest dan Posttest).

Berdasarkan pengujian hipotesis pertama, dapat disimpulkan bahwa terdapat perbedaan yang signifikan pada keterampilan bertanya siswa kelompok eksperimen sebelum dan sesudah diberikan layanan penguasaan konten menggunakan model pembelajaran kooperatif tipe think pair share, yakni terjadi peningkatan yang signifikan keterampilan bertanya siswa kelompok eksperimen setelah diberikan perlakuan. Berdasarkan hasil penelitian Zuliani Fariska (2011) yang di lakukan di Angkek Kabupaten Agam menjelaskan hasil belajar mata pelajaran teknologi informasi dan komunikasi dengan menggunakan model pembelajaran kooperatif lebih tinggi dari pada nilai dengan menggunakan metode ceramah atau konvensional, ini terbukti dari peningkatan keterampilan bertanya siswa berdasarkan hasil penyebaran instrumen keterampilan bertanya.

Supriyadi (2011:158) menjelaskan keterampilan bertanya adalah usaha untuk memahami sesuatu yang belum dimengerti. Menurut Prayitno (2002:27) keterampilan bertanya merupakan unsur penting yang perlu dikuasai siswa, mengingat bahwa siswa perlu mendalami materi yang dibahas dalam proses belajar mengajar, bertanya untuk mengetahui sesuatu yang belum jelas atau belum dipahami maka dari itu pertanyaan yang hendak ditanyakan adalah sesuatu yang tidak dimengerti.

Menggunakan strategi khusus dalam proses pembelajaran maupun pemberian layanan merupakan pilihan yang tepat agar proses belajar menjadi lebih efektif. Hal tersebut juga dapat dilakukan dalam meningkatkan keterampilan bertanya siswa. Dengan demikian, cara peneliti untuk meningkatkan keterampilan bertanya siswa adalah dengan cara memberikan layanan penguasaan konten menggunakan model pembelajaran kooperatif tipe think pair share. Meningkatkan keterampilan bertanya siswa merupakan salah satu tugas dan tanggung jawab guru BK atau konselor sekolah. Adapun bantuan yang diberikan dapat melalui layanan BK, diantaranya melalui layanan penguasaan konten. Pemberian layanan penguasaan konten (PKO) merupakan layanan bantuan kepada individu (sendiri ataupun kelompok) untuk menguasai kemampuan atau kompetensi tertentu melalui kegiatan belajar (Prayitno, 2012:89).

Pada penelitian ini, model pembelajaran kooperatif tipe think pair share yang dilaksanakan adalah dengan menetapkan materi dan masalah yang hendak didiskusikan. Kemudian peneliti menjelaskan tata cara dalam pelaksanaan think pair share tersebut. Setelah siswa menyajikan hasil diskusi, siswa lain yang menyimak dimintai pendapatnya serta komentar terhadap materi yang disampaikan pasangan penyaji, sehingga pada akhir pembelajaran siswa bersama-sama melatih keterampilan bertanya berdasarkan materi yang telah mereka diskusikan bersama.

Keberhasilan pemberian layanan penguasaan konten menggunakan model pembelajaran kooperatif tipe think pair share diperkuat dengan hasil temuan pada hipotesis pertama yang menyatakan bahwa terdapat perbedaan yang signifikan pada keterampilan bertanya siswa kelompok eksperimen sebelum dan sesudah diberikan layanan penguasaan konten menggunakan model pembelajaran kooperatif tipe 
think pair share. M. Royani \& Bukhari Muslim(2004) menjelaskan terdapat peningkatan keaktifan siswa dalam proses pembelajaran menggunakan strategi pembelajaran inovatif. Untuk menunjang keterampilan bertanya siswa dengan menggunakan strategi pembelajaran aktif dan inovatif.

Berdasarkan hal yang telah dijelaskan di atas, maka layanan penguasaan konten menggunakan model pembelajaran kooperatif tipe think pair share dapat diberikan dalam rangka meningkatkan keterampilan bertanya siswa dalam belajar. Dengan adanya layanan penguasaan konten menggunakan model pembelajaran kooperatif tipe think pair share, menjadikan siswa lebih aktif dalam mengikuti proses pembelajaran dikarenan proses pembelajaran tidak lagu berpusat pada guru, akan tetapi lebih kepada siswa

2. Perbedaan Keterampilan Bertanya Siswa dalam Belajar Kelompok Kontrol (Pretest dan Posttest).

Pemberian layanan penguasaan konten untuk meningkatkan keterampilan bertanya siswa pada kelompok kontrol dilakukan tanpa menggunakan model pembelajaran. Dari data hasil penelitian, diketahui bahwa tidak terdapat perbedaan yang signifikan pada keterampilan bertanya siswa kelompok kontrol sebelum dan sesudah diberi perlakuan. Dikatakan tidak signifikan karena hanya terjadi perbedaan mean sebelum dan sesudah diberi perlakuan, sementara tidak terjadinya perbedaan kategori. Perubahan tersebut dikarenakan kelompok kontrol tidak mendapat perlakuan khusus yaitu layanan penguasaan konten menggunakan model pembelajaran kooperatif tipe think pair share.

Berdasarkan jurnalnya, Aninditya Sri Nugraheni (2012), menjelaskan terdapat peningkatan kualitas pembelajaran (baik proses maupun hasil) pada keterampilan berbicara siswa kelas V Madrasah Ibtidaiyah Pucangan, Kartasura, Sukoharjo. Peningkatan kualitas pembelajaran dengan penerapan strategi Think-Pair-Share, yaitu ini terbukti siswa menjadi lebih berani setelah dilatih oleh guru dengan menggunakan strategi Think-Pair-Share, siswa yang lebih berperan aktif dalam mengikuti pelajaran, siswa menjadi merasa tertantang untuk bisa ikut aktif dalam proses pembelajaran.

Layanan penguasaan konten dalam meningkatkan keterampilan bertanya siswa kelompok kontrol diberikan tanpa menggunakan model pembelajaran kooperatif tipe think pair share, yaitu teknik ceramah dan tanya jawab. Senada dengan pernyataan tersebut, metode atau teknik yang digunakan dalam penyajian layanan penguasaan konten menurut Prayitno (2012:97) adalah penyajian, tanya jawab dan diskusi.Pemberian layanan penguasaan konten tanpa menggunakan model pembelajaran kooperatif tipe think pair share ini menyajikan materi yang sama diberikan pada kelas eksperimen. Materi keterampilan bertanya yang diberikan meliputi keteraampilan menandai materi belajar yang sulit dipahami, menulis pertanyaan, meminta kesempatan bertanya, dan mengajukan pertanyaan dengan singkat dan jelas. Pemberian layanan penguasaan konten tanpa menggunakan model pembelajaran kooperatif tipe think pair share menjadikan guru yang lebih aktif dalam proses pembelajaran, sehingga siswa hanya menerima penjelasan yang disampaikan oleh guru. Pada hasil penelitian ini tergambarlah bahwa pemberian layanan penguasaan konten menggunakan model pembelajaran kooperatif tipe think pair share lebih efektif untuk meningkatkan keterampilan bertanya siswa dibandingkan pemberian layanan penguasaan konten tanpa menggunakan model pembelajaran.

3. Perbedaan Keterampilan Bertanya Siswa dalam Belajar Kelompok Eksperimen dan Kelompok Kontrol.

Tujuan dari penelitian ini adalah untuk mengetahui perbedaan efektivitas layanan penguasaan konten dengan model pembelajaran kooperatif tipe think pair share pada kelompok eksperimen dan layanan penguasaan konten tanpa menggunakan model pembelajaran pada kelompok kontrol dalam meningkatkan keterampilan bertanya siswa dalam belajar. Hasil penelitian menunjukan bahwa terdapat perbedaan yang signifikan pada keterampilan bertanya siswa yang diberi layanan penguasaan konten menggunakan model pembelajaran kooperatif tipe think pair share dengan kelompok kontrol yang diberi layanan penguasaan konten tanpa model pembelajaran.

Berdasarkan hasil uji statisitik menunjukan adanya perbedaan keterampilan bertanya siswa pada kelompok eksperimen dan kelompok kontrol. Perbedaan keterampilan bertanya siswa terjadi karena adanya perbedaan perlakuan yang diterima oleh masing-masing kelompok. Meskipun materi dan banyaknya perlakuan yang diberikan sama-sama berjumlah 4 kali. Kelompok kontrol diberikan perlakuan berbeda dari kelompok ekperimen yaitu pemberian layanan penguasaan konten tanpa menggunakan model pembelajaran kooperatif tipe think pair share.

L. Surayya, I W. Subagia \& I N. Tika (2014) pada penelitiannya menemukan terdapat perbedaan hasil belajar antara siswa yang mengikuti model pembelajaran TPS dengan siswa yang mengikuti model pembelajaran konvensional, dimana terdapat peningkatan hasil belajar yang signifikan pada siswa yang menerima penerapan model pembelajaran TPS dibandingkan siswa yang menerima penerapan model pembelajaran konvensional. Rahmatun Nisa, Edwin Musdi, Jazwinarti (2014) menjelaskan hasil belajar matematika siswa yang menggunakan model pembelajaran kooperatif tipe think pair share lebih baik dari pada hasil belajar matematika siswa yang menggunakan pembelajaran konvensional di Kelas XI IPS SMA Negeri 2 Padang Panjang. 
Peneliti memberikan materi dan konten-konten mengenai keterampilan bertanya siswa dengan teknik ceramah dan tanya jawab. Kemudian peneliti mempersilahkan siswa untuk bertanya apabila terdapat hal yang belum dipahami. Sebelum menjawab beberapa pertanyaan dari siswa, pertanyaan tersebut terlebih dahulu dilemparkan forum dengan tujuan agar siswa-siswa yang lain ikut berpikir mengenai pertanyaan yang dikemukakan. Lalu siswa diminta menerapkan dan berlatih sesuai konten yang diajarkan Selama proses pembelajaran berlangsung, siswa cukup antusias mengikuti kegiatan pada beberapa materi. Siswa yang aktif biasanya selalu sama pada setiap pertemuan, dan sulit untuk mendorong siswa yang lain untuk ikut aktif.

Selanjutnya, untuk kelompok eksperimen diberikan perlakuan layanan penguasaan konten menggunakan model pembelajaran kooperatif tipe think pair share. Menurut Arianti (2011: 5) pembelajaran think pair share merupakan suatu cara yang efektif untuk membuat variasi suasana pola diskusi kelas. Pembelajaran koopertif tipe TPS merupakan pembelajaran kelompok dimana siswa diberi kesempatan untuk berfikir mandiri dan saling membantu dengan teman yang lain. Pembelajaran TPS membimbing siswa untuk memiliki tanggung jawab individu dan tanggung jawab dalam kelompok atau pasangannya. dan mengatasi masalah-masalahnya.

\section{Kesimpulan}

Berdasarkan data dan hasil penelitian yang telah diperoleh, maka secara khusus temuan dalam penelitian ini adalah sebagai berikut :

1. Terdapat perbedaan yang signifikan pada keterampilan bertanya siswa kelompok eksperimen sebelum dan sesudah diberikan layanan penguasaan konten menggunakan model pembelajaran kooperatif tipe think pair share.

2. Tidak terdapat perbedaan yang signifikan pada keterampilan bertanya siswa kelompok kontrol sebelum dan sesudah diberikan perlakuan layanan penguasaan konten tanpa menggunakan model pembelajaran.

3. Terdapat perbedaan yang signifikan pada keterampilan bertanya siswa antara kelompok eksperimen yang mengikuti layanan penguasaan konten menggunakan model pembelajaran kooperatif tipe think pair share dan keterampilan bertanya siswa kelompok kontrol yang mengikuti layanan penguasaan konten tanpa menggunakan model pembelajaran.

Hasil pengujian ketiga hipotesis dalam penelitian ini menunjukan bahwa layanan penguasaan konten menggunakan model pembelajaran kooperatif tipe think pair share lebih efektif dalam meningkatkan keterampilan bertanya siswa dalam belajar. Layanan penguasaan konten tanpa menggunakan model pembelajaran juga dapat meningkatkan keterampilan bertanya siswa, namun peningkatan rata-rata skor tidak sebanyak pada layanan penguasaan konten dengan model pembelajaran kooperatif tipe think pair share.

\section{Kepustakaan}

Amri Nur Syihab (2013). Penerapan Model Pembelajaran Think-Pair-Share Melalui Public Speaking untuk Meningkatkan Keterampilan Komunikasi Siswa (Pada Mapel Kompetensi Kejuruan Kompetensi Dasar MC Kelas X1 AP 1 Jurusan Administrasi Perkantoran SMK N 2 Blora Tahun Ajaran 2012/2013). Skripsi. Semarang: Jurusan Pendidikan Ekonomi Universitas Negeri Semarang.

Aninditya Sri Nugraheni (2012). Optimalisasi Strategi Cooperative Learning Tipe Think-Pair-Share (Tps) Untuk Meningkatkan Kompetensi Berbicara Siswa Kelas V MI. Jurnal. Surakarta: Progam Pasca Sarjana UNS.

Dewa Ketut Sukardi \& Desak P.E. Nila Kusmawati (2008).Proses Bimbingan dan Konseling di Sekolah. Jakarta: Rineka Cipta

Hezy Desyafmi, Firman \& Ifdil (2014). Peningkatan Motivasi Siswa Dalam Menyelesaikan Tugas Melalui Layanan Informasi. Jurnal. http://ejournal.unp.ac.id/index.php/konselor.

Khairul Amri, Syahniar \& Herman Nirwana (2014). Peningkatan Kemampuan Mengemukakan Pendapat Melalui Layanan Bimbingan Kelompok. Jurnal. http://ejournal.unp.ac.id/index.php/konselor 
L. Surayya, I W. Subagia \& I N. Tika (2014). Pengaruh Model Pembelajaran Think Pair Share Terhadap Hasil Belajar Ipa Ditinjau dari Keterampilan Berpikir Kritis Siswa. E-Journal Program Pascasarjana Universitas Pendidikan Ganesha: Volume 4.

M. Royani \& Bukhari Muslim (2004). Keterampilan Bertanya Siswa Smp Melalui Strategi Pembelajaran Aktif Tipe Team Quiz Pada Materi Segi Empat. Jurnal: Pendidikan Matematika STKIP Banjarmasin, Volume 2 nomor 1.

Muhibbin Syah (2012). Psikologi Belajar. Jakarta: Rajagrafindo Persada.

Natawidjaja (1999). Pedoman Supervisi. Jakarta: Depdiknas.

Prayitno (1988). Orientasi bimbingan dan konseling. Jakarta: Depdikbud

Prayitno (1997). Seri Pemandu Pelaksanaan Bimbingan dan Konseling di Sekolah. Padang:BK FIP UNP.

Prayitno (2012). Jenis Layanan dan Kegiatan Pendukung Konseling. Padang: BK FIP UNP.

Rahmatun Nisa, Edwin Musdi \& Jazwinarti (2014). Penerapan Pembelajaran Kooperatif Tipe Think Pair Share Pada Pembelajaran Matematika di Kelas XI Ips Sma Negeri 2 Padang Panjang. Jurnal Pendidikan Matematika: Vol. 3 No. 1. FMIPA UNP

Satya Anggi Perman, Syahniar \& Daharnis (2014). Pelaksanaan Layanan Bimbingan dan Konseling di Sekolah Menengah Atas Negeri (SMAN) 4 Kerinci. Jurnal. http://ejournal.unp.ac.id/index.php/konselor.

Suharsimi Arikunto (2010). Manajemen Penelitian. Jakarta: Rineka Cipta.

Supriyadi (2011). Strategi Belajar dan Mengajar. Yogyakarta: Cakrawala Ilmu

Syiddik Khutami (2015). Efektivitas Layanan Penguasaan Konten untuk Meningkatkan Keterampilan Belajar Siswa. Skripsi. Padang: BK FIP UNP.

The Liang Gie (2002). Cara Belajar yang Efisien: Jilid I Edisi ke 5. Yogyakarta: Pusat Belajar Ilmu Berguna.

Trianto (2009). Mendesain Model Pembelajaran Inovatif-Progresif. Jakarta: Kencana

Willi Purwanti, Firman, \& Afrizal Sano (2013). Hubungan Persepsi Siswa Terhadap Pelaksanaan Asas Kerahasiaan Oleh Guru BK Dengan Minat Siswa untuk Mengikuti Konseling Perorangan.Jurnal. Jurusan Bimbingan dan Konseling FIP UNP 